\title{
PERBAIKAN FREENESS DAN MUTU KERTAS BEKAS MENGGUNAKAN CELLULOSE BINDING DOMAIN DARI ENDOGLUKANASE Egl-II
}

\author{
Rina Masriani ${ }^{1}$, Taufan Hidayat, Henggar Hardiani \\ Balai Besar Pulp dan Kertas 1, Jl. Raya Dayeuhkolot No. 132 Bandung \\ ${ }^{1}$ rina.masriani@gmail.com
}

Diterima : 5 Mei 2014, Revisi akhir : 8 Oktober 2014, Disetujui terbit : 3 November 2014

\section{FREENESS AND WASTE PAPER QUALITY IMPROVEMENT USING CELLULOSE-BINDING DOMAIN OF ENDOGLUCANASE Egl-II}

\begin{abstract}
The objective of this research is improving the freeness of waste paper stock and paper quality by using the Cellulose Binding Domain (CBD) of endoglucanase Egl-II. CBD has been separated from endoglucanase Egl-II by proteolysis method. CBD has a molecular weight of approximately $21 \mathrm{kD}$. The produced CBD contained $0.04 \mathrm{mg} / \mathrm{mL}$ protein and did not show the total enzyme activity. Waste paper disintegrated using Niagara beater with no load at the consistency of $1.5 \%$. CBD was applied to the refined waste paper fibers with a freeness of $200 \mathrm{~mL} C S F$ (Canadian Standard Freeness). The dosages of CBD used for waste paper treatment were 0.2 and $0.3 \mathrm{mg} \mathrm{CBD/g}$ of oven-dried pulp. The result shows that this treatment increases the freeness of fibers by $140 \mathrm{~mL} \mathrm{CSF} \mathrm{(70 \% ).} \mathrm{CBD} \mathrm{also} \mathrm{increases} \mathrm{the}$ amount of removed water from the fibers from $290 \mathrm{~mL}$ to $390 \mathrm{~mL}$ and $370 \mathrm{~mL}$, respectively, using the dynamic drainage jar (DDJ) measurement. The cellobiose assay of the waste paper filtrate treated with $C B D$ shows no sugar dissolution, which indicates no cellulose degradation. The tear index of paper produced by treatment with CBD shows insignificant change. The Concora Medium Test (CMT) of paper produced by treatment with CBD has higher tensile index, burst index, and ring crush.
\end{abstract}

Keywords: cellulose-binding domain, endoglucanase Egl-II, freeness improvement, waste paper

\begin{abstract}
ABSTRAK
Tujuan penelitian ini adalah untuk memperbaiki freeness dari stok kertas bekas dan mutu lembaran kertas yang dihasilkan dengan menggunakan Cellulose Binding Domain (CBD) dari endoglukanase Egl-II. CBD yang digunakan merupakan hasil pemisahan dari endoglukanase Egl-II dengan metode proteolisis. CBD ini memiliki berat molekul sekitar $21 \mathrm{kD}$. CBD yang dihasilkan mengandung kadar protein sebesar $0,04 \mathrm{mg} / \mathrm{mL}$ dan tidak terdeteksi adanya aktivitas total enzim. Kertas bekas diuraikan dengan menggunakan Niagara beater tanpa beban pada konsistensi 1,5\%. CBD diaplikasikan pada serat kertas bekas yang telah digiling dan memiliki freeness $200 \mathrm{~mL}$ CSF (Canadian Standard Freeness). Dosis CBD yang digunakan untuk perlakuan terhadap serat kertas bekas adalah 0,2 dan $0,3 \mathrm{mg} \mathrm{CBD} / \mathrm{g}$ pulp kering-oven. Hasil penelitian menunjukkan perlakuan dengan CBD meningkatkan freeness bubur serat kertas bekas sebesar $140 \mathrm{~mL}$ CSF (70\%). CBD juga meningkatkan volume air yang dihilangkan dari serat kertas bekas dari $290 \mathrm{~mL}$ menjadi $390 \mathrm{~mL}$ dan $370 \mathrm{~mL}$ menggunakan pengukuran dynamic drainage jar (DDJ). \%FPR meningkat dari 98,80\% menjadi 99,77\%. Pengujian selobiosa terlarut pada filtrat serat kertas bekas yang telah mengalami perlakuan dengan CBD memperlihatkan tidak ada gula terlarut, artinya tidak ada degradasi selulosa menjadi gula terlarut. Indeks sobek dari kertas yang dihasilkan melalui perlakuan dengan CBD memperlihatkan tidak ada perubahan yang signifikan. Nilai tensile index, burst index, ring crush dan Concora Medium Test (CMT) dari kertas yang dihasilkan melalui perlakuan dengan CBD meningkat.
\end{abstract}

Kata kunci: cellulose-binding domain, endoglukanase Egl-II, perbaikan freeness, kertas bekas 


\section{PENDAHULUAN}

Penelitian tentang perbaikan mutu kertas bekas merupakan penelitian yang perlu dilakukan karena kertas bekas merupakan sumber bahan baku yang penting saat ini pada industri kertas baik tingkat nasional maupun internasional. Beberapa pabrik kertas di Indonesia, diantaranya PT. Fajar Paper dan PT Aspec Kumbong, saat ini telah 100\% menggunakan kertas bekas sebagai bahan baku. Menurut Direktorat Jenderal Industri Agro dan Kimia (2011), kebutuhan kertas bekas untuk industri kertas nasional pada tahun 2010 adalah sekitar 6,7 juta ton per tahun, sekitar 4,3 juta ton dipasok dari pengumpulan kertas bekas lokal, sisanya sekitar 2,4 juta ton berasal dari kertas bekas impor. Kelebihan serat kertas bekas dibandingkan serat virgin sebagai bahan baku kertas adalah harga yang jauh lebih murah dan sudah mengandung bahan kimia kertas sehingga penggunaan bahan kimia pada pembuatan kertas dapat jauh dikurangi. Peningkatan penggunaan kertas bekas sebagai bahan baku kertas lebih ramah terhadap lingkungan karena satu ton pembuatan kertas dari serat kertas bekas dapat menghemat 25-30 $\mathrm{m}^{3}$ air, 20-30 pohon, sekitar $4000 \mathrm{kWh}$ listrik dan menurunkan polusi lingkungan karena hanya sedikit menggunakan bahan kimia jika dibandingkan pembuatan kertas dari serat virgin (Dienes, 2006). Sedangkan kelemahannya adalah mutu kertas yang dihasilkan lebih rendah dan laju penghilangan airnya lebih lambat jika dibandingkan serat virgin (Pala, dkk., 2001; Dienes, 2006).

Kertas bekas yang banyak digunakan sebagai bahan baku adalah kotak karton gelombang bekas (kardus/boks) dengan kualitas rendah, yaitu kardus kemasan mie instan. Kardus kemasan mie instan dibentuk dari karton gelombang muka ganda atau dinding tunggal (single wall) yang terdiri dari 2 kertas lainer (L1 dan L2) dan 1 kertas medium bergelombang $(\mathrm{M})$ dengan gramatur L1/M/L2 adalah $125 \mathrm{GSM} / 112 \mathrm{GSM} / 125 \mathrm{GSM}$. Hasil survei ke beberapa pabrik boks di Indonesia, yang secara praktis menggolongkan kualitas kotak karton gelombang berdasarkan penggunaannya. Hal ini ditentukan karena persyaratan spesifikasi untuk kotak karton gelombang diantaranya adalah berat maksimal kotak beserta isinya. Semakin berat isi kotak karton gelombang maka diperlukan kotak karton gelombang dengan kualitas yang semakin tinggi, dan semakin ringan isi kotak karton gelombang dapat digunakan kotak karton gelombang dengan kualitas yang lebih rendah. Berdasarkan hal tersebut maka penggolongan kotak karton gelombang dari kualitas tertinggi ke kualitas terendah adalah sebagai berikut:

1. Kotak karton gelombang untuk kemasan margarin/tembakau

2. Kotak karton gelombang untuk kemasan oli

3. Kotak karton gelombang untuk kemasan makanan (coklat)

4. Kotak karton gelombang untuk kemasan yang bersifat umum

5. Kotak karton gelombang untuk kemasan mie/ makanan ringan

6. Karton gelombang untuk devider/pemisah gelas.

Untuk mengatasi kelemahan kertas bekas dapat digunakan cellulose binding domain (CBD) pada proses pembuatan kertas dari bahan baku serat kertas bekas. CBD memiliki potensi aplikasi sebagai aditifdalam industri kertas karena CBD dapat memodifikasi serat polisakarida pada kapas, kayu atau kertas (Lemos, dkk., 2000; Levy dan Shoseyov, 2002). Menurut Pala, dkk. (2001), perlakuan pulp dengan CBD meningkatkan laju drainase dan indeks ketahanan pulp kertas (khususnya indeks tarik dan indeks retak) yang simultan dibandingkan dengan kontrol. Pada dosis yang lebih rendah $(0,4-1,4 \mathrm{mg}$ protein/g kering oven pulp), meningkatkan drainase sebesar $14 \%$, 9\% indeks retak dan 7\% indeks tarik). Menurut Machado, dkk. (2009), aplikasi carbohydrate binding module (CBM3) dari Clostridium thermocellumscaffolding protein (CipA) pada pulp E. globulus meningkatkan indeks retak, indeks tarik, menurunkan permeability dan tidak ada efek terhadap indeks sobek.

Hasil BLAST(P) endoglukanase Egl-II menunjukkan modular enzim ini tersusun dari signal peptida (1-29), catalytic domain (48301) dari glycosyl hydrolase famili 5 (GH5) dan substrate binding domain (356-437) dari cellulose binding module 3 (CBM 3) (Nurachman, dkk., 2010). CBD dari endoglukanase Egl-II dapat dipisahkan dengan metode proteolisis (Masriani, dkk., 2013). CBD atau cellulose binding module (CBM) adalah modul fungsional dari gen carbohydrate-active enzyme yang berfungsi mempromosikan adsorpsi enzim ke ke kristal selulosa tak larut (Henrissat dan Davies, 2000; Carrard, G., dkk. 2000). Menurut Tormo dkk (1996), binding domain ini adalah domain yang berbeda dari enzim bebas, terhubung dengan satu 
atau lebih katalitik domain. Ada juga CBD yang merupakan subunit dengan ciri-ciri tersendiri yang tergabung dengan domain non katalitik tambahan yang disebut cellulosome. CBD mempunyai peran penting dalam mediasi pengikatan enzim selulolitik atau mikroorganisme penghasilnya ke permukaan substrat selulosa, melakukan gangguan non hidrolitik pada serat selulosa. Tahap ini merupakan titik inisiasi pada proses degradasi selulosa (Tormo dkk, 1996). Protein ini akan mengikat permukaan serat, dengan memodifikasi permukaan atau sifat antarmuka dari serat (Henrissat dan Davies, 2000). Kelebihan dari protein ini dalam memperbaiki sifat kertas bekas adalah tidak ada degradasi selulosa terjadi selama proses modifikasi serat. Tujuan penelitian ini adalah untuk memperbaiki freeness dari stok kertas bekas dan mutu lembaran kertas yang dihasilkan dengan menggunakan CBD dari endoglukanase Egl-II.

\section{BAHAN DAN METODE}

\section{Bahan}

Endoglukanase Egl-II diekspresi oleh Bacillus megaterium yang membawa plasmid $\mathrm{PMM}_{1525 \text {-egII }}$ secara ekstrasel. B. megaterium ini diperoleh dari Laboratorium Biokimia, Institut Teknologi Bandung. Cellulase dari Aspergillus niger, (Sigma, Index-No. : 647-002-00-3). Bahanbahan kimia p.a yang terdiri dari tripton, ekstrak ragi, $\mathrm{NaCl}$, tetrasiklin, pepton, xilosa, bovine serum albumin (BSA), karboksi metilselulosa, asam dinitrosalisilat, selobiosa, Bradford reagent, papain dari papaya latex (Sigma Co. Ltd), dan air destilat. Polysulfone membrane (PM) dengan ukuran pori $10 \mathrm{kDa}, 30 \mathrm{kDa}$ and $50 \mathrm{kDa}$. Sampel kertas bekas yang digunakan adalah kardus bekas dengan kualitas rendah yang diperoleh secara acak dari daerah Baleendah dan Dayeuhkolot, Kabupaten Bandung, Jawa Barat.

\section{Metode}

\section{Produksi, Uji Aktivitas, dan Uji Kadar Protein Endoglukanase Egl-II}

Endoglukanase Egl-II dibuat sesuai dengan metode produksi menurut Masriani dan Nurachman (2012); MoBiTec (2008). Pemekatan endoglukanase dilakukan menggunakan metode ultrafiltrasi (Lestari, dkk., 2000; Masriani, dkk., 2013). Aktivitas endoglukanase Egl-II dalam menghidrolisis karboksi metilselulosa (CMC) ditentukan dari jumlah gula pereduksi yang dilepas. Kondisi inkubasi $\mathrm{CMC}$ oleh endoglukanase Egl-II mengacu pada kondisi menurut Masriani dan Nurachman (2012). Kadar gula pereduksi yang dilepas ditentukan dengan pereaksi asam dinitrosalisilat (DNS) menggunakan selobiosa sebagai standar (Miller, 1959). Masing-masing pengukuran absorbansi dilakukan tiga kali (triplo). Satu unit aktivitas endoglukanase Egl-II didefinisikan sebagai jumlah enzim yang mampu melepaskan $1 \mu \mathrm{mol}$ gula pereduksi per menit pada kondisi reaksi. Aktivitas spesifik enzim didefinisikan sebagai unit aktivitas per mg protein. Kadar protein enzim ditentukan dengan metode Bradford menggunakan BSA sebagai standar (Bradford, 1976). Masing-masing pengukuran absorbansi dilakukan tiga kali (triplo).

\section{Digestasi Endoglukanase Egl-II dan Pemisahan CBD dari Endoglukanase Egl-II dengan Cara Ultrafiltrasi}

Digestasi endoglukanase Egl-II dilakukan dengan menggunakan enzim papain. Menurut Masriani dkk. (2013), perbandingan endoglukanase Egl-II/papain yang optimum adalah 50:1 (w/w). Kondisi ini diperoleh dengan cara mencampurkan larutan papain $(1 \mathrm{mg} / \mathrm{mL})$ dan $100 \mathrm{~mL}$ crude endoglucanase Egl-II (0,0533 $\mathrm{mg} / \mathrm{mL}$ ). Campuran diagitasi selama 4 jam pada temperatur $\pm 23^{\circ} \mathrm{C}$ (Lemos, dkk., 2000; Yokota, dkk., 2008). Protein hasil digestasi dipisahkan dengan cara ultrafiltrasi. Menurut Masriani, dkk. (2013), hasil ultrafiltrasi terdiri dari dua bagian yaitu permeat yang berisi CBD dan feed yang berisi campuran CD-CBD-(Egl-II). Kadar protein permeat dan feed hasil ultrafiltrasi ditentukan dengan metode Bradford menggunakan BSA sebagai standar (Bradford, 1976). Pada permeat dan feed hasil ultrafiltrasi juga dilakukan uji aktivitas endoglukanase Egl-II. CBD dan campuran CD-CBD-(Egl-II) digunakan sebagai aditif pada perlakuan serat kertas bekas sebelum dibuat lembaran.

\section{Aplikasi CBD dari Endoglukanase Egl-II untuk Perbaikan Mutu Kertas Bekas}

Bubur serat kertas bekas disiapkan sesuai prosedur menurut Masriani dan Nurachman 
(2012). Freeness awal kertas bekas adalah 490 mL CSF (Canadian Standard Freeness). Bubur serat kertas bekas yang siap digunakan adalah bubur dengan freeness $200 \mathrm{~mL}$ CSF dan konsistensi 3\%.

Sebelum dibuat lembaran kertas, pada bubur serat kertas bekas dilakukan perlakuan menggunakan aditif. Aditif yang digunakan adalah CBD dan campuran CD-CBD-(Egl-II). Dosis aditif dihitung berdasarkan mg protein aditif per g pulp kering-oven. Dosis aditif yang digunakan adalah $0,2 \mathrm{mg} \mathrm{CBD} / \mathrm{g}$ pulp keringoven; $0,3 \mathrm{mg} \mathrm{CBD} / \mathrm{g}$ pulp kering-oven; 0,2 mg CD-CBD-(Egl-II)/g pulp kering-oven; 0,4 mg CD-CBD-(Egl-II)/g pulp kering-oven; dan dilakukan perlakuan blanko. Perlakuan bubur serat kertas bekas dengan aditif dilakukan pada suhu $50^{\circ} \mathrm{C}$, kecepatan putaran 150 rpm, dan waktu perlakuan selama 30 menit. Perlakuan dihentikan dengan cara mendidihkan campuran selama 5 menit. Perlakuan blanko dilakukan dengan cara yang sama, tetapi tanpa menggunakan aditif.

Sebelum dan sesudah perlakuan dengan aditif dilakukan pengukuran angka freeness dan volume penghilangan air dengan wadah dinamik drainase, penentuan kadar fines, dan uji kadar selobiosa. Pengukuran angka freeness dan volume penghilangan air dengan wadah dinamik drainase serta penentuan kadar fines dilakukan untuk mengetahui pengaruh CBD terhadap retensi dan drainase stok bubur kertas. Pengukuran angka freeness dilakukan sesuai prosedur menurut Masriani dan Nurachman (2012). Volume penghilangan air dengan wadah dinamik drainase dilakukan sesuai prosedur menurut Masriani (2011). Uji kadar selobiosa dilakukan dengan pereaksi asam dinitrosalisilat (DNS) (Miller, 1959) untuk mengetahui pengaruh CBD terhadap degradasi selulosa sebagai komponen kimia utama pada kertas bekas menjadi gula-gula terlarut. Uji kadar fines dilakukan untuk mengetahui persentase serat selulosa halus yang lolos pada saat pembuatan kertas. Pengaruh perlakuan dengan CBD dan campuran CD-CBD-(Egl-II) dibandingkan terhadap blanko.

\section{Pembuatan Lembaran Kertas dan Pengujian Sifat Fisik Lembaran Kertas}

Tahap pembuatan lembaran kertas meliputi pembuatan lembaran basah, pengepresan, dan pengeringan lembaran. Pembuatan lembaran ini dilakukan dengan mengacu pada SNI 14-04891989. Untuk setiap variabel dibuat 6 (enam) lembaran kertas.

Lembaran kertas yang dihasilkan ditentukan gramaturnya berdasarkan SNI ISO 536:1995 Kertas dan karton - Cara uji gramatur. Penentuan nilai indeks retak mengacu pada metode SNI ISO 2758:2001 Kertas - Cara uji ketahanan retak. Nilai indeks retak dihitung dari nilai ketahanan retak kertas, dalam kiloPaskal, dibagi dengan gramatur. Penentuan nilai indeks tarik mengacu pada metode SNI ISO 1924-2: 2010 Kertas dan karton - Cara uji sifat tarik -Bagian 2: Metode kecepatan elongasi tetap. Nilai indeks tarik dihitung dari nilai ketahanan tarik (dinyatakan dalam kiloNewton per meter) dibagi dengan gramatur. Penentuan nilai indeks sobek mengacu pada metode SNI ISO 0436:2009 Kertas - Cara uji ketahanan sobek - Metode Elmendorf. Nilai indeks sobek dihitung dari nilai ketahanan sobek dibagi dengan gramatur. Penentuan nilai ketahanan tekan lingkar (ring crush tester/RCT) mengacu pada metode SNI ISO 12192:2010 Kertas dan karton - Ketahanan tekan - metode tekan lingkar. Penentuan nilai ketahanan tekan datar (Concora medium test/CMT) mengacu pada metode SNI ISO 7263:2010 Kertas medium - Cara uji ketahanan tekan datar setelah penggelombangan di laboratorium. Masingmasing pengukuran dilakukan 10 (sepuluh) kali.

\section{HASIL DAN PEMBAHASAN}

\section{Hasil Produksi, Pemekatan, Digestasi Endoglukanase Egl-II dan Pemisahan Cellulose Binding Domain dari Endoglukanase Egl-II}

Produksi endoglukanase Egl-II dilakukan berdasarkan metode menurut Masriani dan Nurachman (2012) dan metode pemekatan endoglukanase Egl-II dan pemisahan CBD dilakukan menurut Masriani, dkk. (2013). Untuk mengetahui kualitas endoglukanase Egl-II hasil produksi dan hasil pemekatan telah dilakukan uji aktivitas total, kadar protein, dan aktivitas spesifik. Pada uji aktivitas enzim, satu unit aktivitas endoglukanase Egl-II didefinisikan sebagai jumlah enzim yang mampu melepaskan $1 \mu \mathrm{mol}$ gula pereduksi per menit pada kondisi reaksi. Aktivitas spesifik enzim didefinisikan sebagai unit aktivitas per mg protein. Data 
kadar protein endoglukanase Egl-II diperlukan untuk menentukan jumlah enzim papain yang ditambahkan untuk proses digestasi. Data aktivitas total, kadar protein, dan aktivitas spesifik setelah proses pemisahan hasil digestasi endoglukanase Egl-II diperlukan untuk re-identifikasi protein yang terdapat pada feed dan permeat. Menurut Masriani, dkk. (2013), hasil ultrafiltrasi terdiri dari dua bagian, yaitu permeat yang berisi CBD dan feed yang berisi campuran CD-CBD-(Egl-II). Data kadar protein diperlukan untuk menentukan dosis CBD yang digunakan pada perlakuan bubur serat kertas bekas.

Crude endoglukanase Egl-II memiliki aktivitas total $0,05 \mathrm{Unit} / \mathrm{mL}$ dan aktivitas spesifik 0,49 Unit/mg protein. Pemekatan dengan metode ultrafiltrasi meningkatkan aktivitas total enzim menjadi 2,39 Unit $/ \mathrm{mL}$ atau meningkat 48 kali, meningkatkan kadar protein dari 102,0 $\mu \mathrm{g} / \mathrm{ml}$ menjadi $980,7 \mu \mathrm{g} / \mathrm{ml}$ atau meningkat 10 kali serta aktivitas spesifik meningkat dari 0,49 Unit/ mg protein menjadi 2,44 Unit/mg protein atau meningkat 5 kali. Sementara selulase komersial dari Aspergillus niger memiliki aktivitas spesifik $\sim 0,8 \mathrm{Unit} / \mathrm{mg}$. CBD yang dihasilkan mengandung kadar protein sebesar $40 \mu \mathrm{g} / \mathrm{ml}$ atau $0,04 \mathrm{mg} / \mathrm{mL}$ dan tidak menunjukkan adanya aktivitas total enzim, artinya hasil pemisahan CBD murni, tidak mengandung catalytic domain (CD). Sedangkan feed memiliki aktivitas total enzim yang lebih tinggi dibandingkan crude endoglukanase Egl-II, artinya $\mathrm{CD}$ telah terpisah dari permeate (CBD) ke dalam feed, bercampur dengan crude Egl-II yang telah terpekatkan sehingga aktivitas spesifiknya menjadi meningkat dari 0,49 Unit/mg menjadi $0,74 \mathrm{Unit} / \mathrm{mg}$.

\section{Aplikasi Cellulose Binding Domain dari Endoglukanase Egl-II untuk Perbaikan Mutu Kertas Bekas}

Freeness awal serat kertas bekas yang digunakan adalah $490 \mathrm{~mL}$ CSF. CBD diaplikasikan pada serat kertas bekas yang telah digiling, memiliki freeness $200 \mathrm{~mL}$ CSF dan konsistensi 3\%. Hasil aplikasi CBD dan campuran CD-CBD-(Egl-II) pada bubur serat kertas bekas dapat dilihat pada Tabel 2. Pengukuran angka freeness dan volume penghilangan air dengan wadah dinamik drainase dilakukan untuk mengetahui pengaruh CBD terhadap drainase stok bubur kertas. Uji kadar fines dilakukan untuk mengetahui persentase serat selulosa halus yang lolos pada saat pembuatan kertas. Uji kadar selobiosa dilakukan untuk mengetahui pengaruh CBD terhadap degradasi selulosa sebagai komponen kimia utama pada kertas bekas menjadi gula-gula terlarut.

Aplikasi CBD pada dosis 0,2 dan 0,3 $\mathrm{mg} \mathrm{CBD} / \mathrm{g}$ kering oven pulp kertas bekas meningkatkan freeness sebesar $140 \mathrm{~mL}$ CSF. CBD juga meningkatkan volume air yang dihilangkan dari bubur serat kertas bekas dari $290 \mathrm{~mL}$ menjadi $390 \mathrm{~mL}$ dan $370 \mathrm{~mL}$ pada pengukuran menggunakan dynamic drainage jar (DDJ). Uji kadar gula selobiosa pada filtrat pulp kertas bekas yang telah mengalami perlakuan dengan CBD bernilai 0,00\% menunjukkan tidak ada gula terlarut, artinya perlakuan dengan CBD tidak menyebabkan degradasi selulosa menjadi gula-gula terlarut. Kadar selobiosa terlarut artinya perlakuan dengan CBD dan mix CD dan Egl-II memodifikasi serat tanpa menyebabkan

Tabel 1. Nilai Aktivitas Total, Kadar Protein dan Aktivitas Spesifik Crude Endoglukanase Egl-II, Endoglukanase Egl-II Hasil Pemekatan, Selulase Komersial, dan Hasil Pemisahan CBD

\begin{tabular}{lccc}
\hline \multicolumn{1}{c}{ Contoh } & $\begin{array}{c}\text { Aktivitas Total } \\
\text { Enzim }(\text { Unit/ml })\end{array}$ & $\begin{array}{c}\text { Kadar Protein } \\
(\mu \mathrm{g} / \mathrm{ml})\end{array}$ & $\begin{array}{c}\text { Aktivitas Spesifik } \\
(\text { Unit/mg protein) }\end{array}$ \\
\hline Crude Endoglukanase Egl-II & 0,05 & 102,0 & 0,49 \\
Endoglukanase Egl-II Hasil Pemekatan & 2,39 & 980,7 & 2,44 \\
Selulase Komersial dari Aspergillus niger & - & - & 0,8 \\
CBD & 0,00 & 40 & - \\
Campuran CD-CBD-(Egl-II) & 0,32 & 430 & 0,74 \\
\hline
\end{tabular}


Tabel 2. Hasil Aplikasi CBD terhadap Bubur Serat Kertas Bekas Dibandingkan Dengan Blanko dan SNI 14-0094-2006 Spesifikasi Kertas Medium

\begin{tabular}{|c|c|c|c|c|c|c|c|c|}
\hline \multirow[t]{2}{*}{$\begin{array}{l}\text { Parameter } \\
\text { Uji }\end{array}$} & \multirow[t]{2}{*}{ Satuan } & \multirow[t]{2}{*}{ Blanko } & \multicolumn{2}{|c|}{ CBD } & \multicolumn{2}{|c|}{$\begin{array}{c}\text { Campuran CD-CBD- } \\
\text { (Egl-II) }\end{array}$} & \multicolumn{2}{|c|}{ SNI Kertas Medium } \\
\hline & & & $\begin{array}{c}0,2 \\
\mathrm{mg} / \mathrm{g} \\
\text { OD } \\
\text { Pulp }\end{array}$ & $\begin{array}{c}0,3 \\
\mathrm{mg} / \mathrm{g} \\
\mathrm{OD} \\
\text { Pulp }\end{array}$ & $\begin{array}{l}0,2 \mathrm{mg} / \mathrm{g} \\
\text { OD Pulp }\end{array}$ & $\begin{array}{l}0,4 \mathrm{mg} / \mathrm{g} \\
\text { OD Pulp }\end{array}$ & Kelas A & Kelas B \\
\hline $\begin{array}{l}\text { Selobiosa } \\
\text { terlarut }\end{array}$ & $(\%)$ & 0,00 & 0,00 & 0,00 & 0,00 & 0,00 & - & - \\
\hline Freeness & $(\mathrm{mL} \mathrm{CSF})$ & 200 & 340 & 340 & 300 & 350 & - & - \\
\hline DDJ & $(\mathrm{mL})$ & 290 & 390 & 370 & 340 & 320 & - & - \\
\hline FPR & $(\%)$ & 98,80 & 99,77 & 99,70 & 99,09 & 99,47 & & \\
\hline Gramatur & $\left(\mathrm{g} / \mathrm{m}^{2}\right)$ & 117 & 112 & 111 & 114 & 108 & 112,0 & 112,0 \\
\hline Bulk & $\left(\mathrm{cm}^{3} / \mathrm{g}\right)$ & 1,54 & 1,73 & 1,62 & 1,53 & 1,56 & $1,54-1,82$ & $1,54-1,82$ \\
\hline $\begin{array}{l}\text { Tensile } \\
\text { strength }\end{array}$ & $(\mathrm{N} / \mathrm{m})$ & 3558 & 3790 & 3711 & 3972 & 3338 & 3190 & 2790 \\
\hline $\begin{array}{l}\text { Tensile } \\
\text { index }\end{array}$ & $(\mathrm{Nm} / \mathrm{g})$ & 30,5 & 33,9 & 33,3 & 34,7 & 30,9 & - & - \\
\hline $\begin{array}{l}\text { Burst } \\
\text { strength }\end{array}$ & $(\mathrm{kPa})$ & 196 & 198 & 202 & 228 & 193 & - & - \\
\hline $\begin{array}{l}\text { Burst } \\
\text { index }\end{array}$ & $\begin{array}{l}(\mathrm{kPa} . \\
\left.\mathrm{m}^{2} / \mathrm{g}\right)\end{array}$ & 1,68 & 1,77 & 1,81 & 1,99 & 1,78 & - & - \\
\hline $\begin{array}{l}\text { Tear } \\
\text { strength }\end{array}$ & $(\mathrm{mN})$ & 720 & 689 & 686 & 710 & 605 & - & - \\
\hline Tear index & $\left(\mathrm{mNm}^{2} / \mathrm{g}\right)$ & 6,2 & 6,2 & 6,2 & 6,2 & 5,6 & - & - \\
\hline $\mathrm{RCT}$ & $(\mathrm{N})$ & 63 & 69 & 70 & 74 & 61 & 110 & 77 \\
\hline CMT & $(\mathrm{N})$ & 85 & 87 & 93 & 102 & 81 & 159 & 142 \\
\hline
\end{tabular}

degradasi berlebihan yang dapat menyebabkan lepasnya selobiosa dari serat selulosa karena terhidrolisis menjadi selobiosa terlarut. Menurut Pala, dkk. (2001), perbaikan mutu kertas terjadi karena CBD mengikat permukaan serat, dengan memodifikasi permukaan/sifat antarmuka dari serat, mempengaruhi sifat teknis dari pulp dan kertas. Kelebihan CBD adalah mengurangi efek peeling mekanis dari permukaan serat yang memperburuk karakteristik pulp akhir. Pengukuran degradasi selulosa mengungkapkan bahwa tidak ada gula terlarut yang terdeteksi selama perlakuan pulp dengan CBD, yang memungkinkan kita untuk memastikan bahwa modifikasi serat tidak terkait dengan hidrolisis enzimatik.

Dari Tabel 2 dapat dilihat bahwa perlakuan dengan CBD meningkatkan semua parameter uji sifat fisik kertas yang diukur jika dibandingkan dengan blanko.Jika dibandingkan dengan SNI 14-
0094-2006 Spesifikasi kertas medium perlakuan dengan CBD sudah memenuhi spesifikasi SNI untuk parameter bulk dan ketahanan tarik namun belum dapat memenuhi nilai mutu ketahanan tekan lingkar dan ketahanan tekan datar.

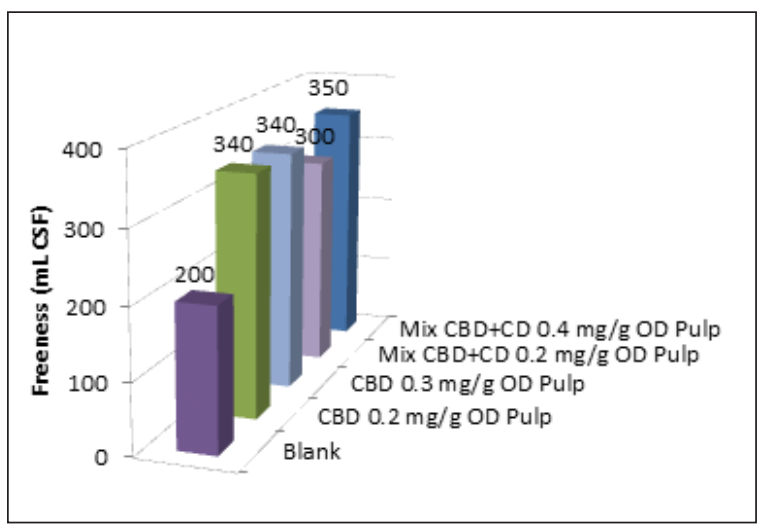

Gambar 1.Pengaruh Perlakuan CBD terhadap Freeness 
Pada Gambar 1 dapat dilihat pengaruh perlakuan CBD terhadap freeness. Perlakuan dengan CBD meningkatkan freeness sebesar $140 \mathrm{ml}$ dibandingkan freeness awal (70\%). Menurut Pala, dkk. (2001), perlakuan pulp dengan CBD pada dosis 0,4 -1,4 mg protein/g pulp kering-oven, meningkatkan drainase sebesar $14 \%$. Pada penelitian ini kenaikan freeness yang dicapai jauh lebih tinggi karena menggunakan CBD yang lebih murni (Masriani, dkk., 2013) jika dibandingkan hasil penelitian Pala, dkk. (2001) yang memisahkan CBD dari selulase Trichoderma reseei dan $\mathrm{CBD}$ yang digunakan masih memiliki aktivitas katalitik, artinya belum terpisah secara murni. Menurut Machado, dkk. (2009), CBM dapat meningkatkan ikatan antar serat karena CBM dapat teradsorpsi ke selulosa secara reversibel, mampu berpindah dari serat selulosa yang satu dan ke serat selulosa yang lainnya dalam suspensi selulosa dan telah dibuktikan dengan metode pelabelan menggunakan fluorochrome FITC (florescein isotiocyanate) dan TRITC (tetramethylrodamine).

Pada Gambar 2 dapat dilihat bahwa perlakuan dengan CBD meningkatkan volume air yang dihilangkan dari serat kertas bekas sampai 134\% jika dibandingkan dengan blanko. Pengukuran volume penghilangan air dengan wadah dinamik drainase dilakukan karena metode ini lebih mendekati kondisi drainase stok bubur kertas yang sebenarnya seperti pada mesin kertas.

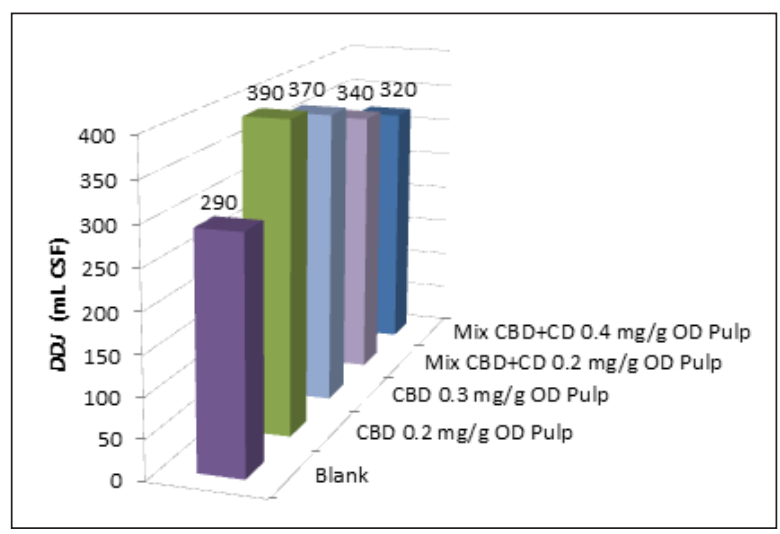

Gambar 2. Pengaruh Perlakuan CBD terhadap DDJ

Perlakuan dengan CBD 0,2 mg/g OD pulp meningkatkan retensi serat dari 98,80\% menjadi 99,77\% (naik 0,97\%) (Gambar 3). Retensi serat meningkat karena kemampuan pengikatan
CBM yang tinggi terhadap selulosa sehingga meningkatkan ikatan antar serat. Menurut Yokota, dkk. (2009), CBM yang diturunkan dari selulase T.viride dan $T$. reesei ( $T v \mathrm{CBM}, \operatorname{Tr} \mathrm{CBM}$ ) dan CBM yang diturunkan dari xylanase $T$. lanuginosus, ( $T l \mathrm{CBM})$, dan secara kovalen dikonjugasi dengan anionik poliakrilamida (A-PAM) meningkatkan retensi aditif pada pembuatan lembaran kertas dari HBKP (hardwood bleached kraft pulp) sebesar $1,6 \mathrm{mg} / \mathrm{g}(0,16 \%), 3,5 \mathrm{mg} / \mathrm{g}(0,35 \%)$ dan 1,5 $\mathrm{mg} / \mathrm{g}(0,15 \%)$. Sementara pada SBKP (softwood bleached kraft pulp) peningkatan retensi yang terjadi adalah sebesar 2,2 mg/g (0,22\%), 2,3 mg/g $(0,23 \%)$ dan $0,1 \mathrm{mg} / \mathrm{g}(0,01 \%)$. Dosis CBM-APAM yang digunakan pada HBKP adalah $0,15 \%$ (w/v) dan pada SBKP 0,4\% (w/v) berdasarkan berat kering pulp. CBM dari selulase lebih efektif dalam meningkatkan retensi serat dibandingkan CBM dari xylanase karena kandungan selulosa dalam serat lebih tinggi jika dibandingkan dengan kandungan xylan.

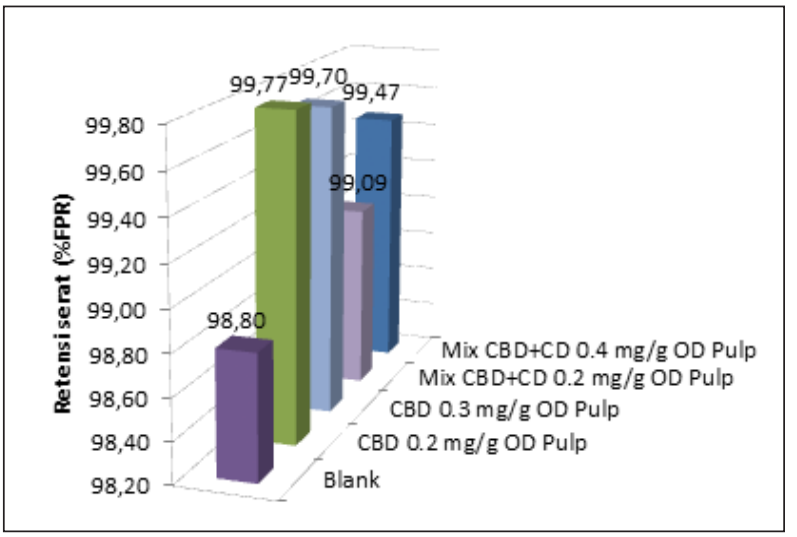

Gambar 3. Pengaruh Perlakuan CBD terhadap Retensi Serat

Perlakuan dengan CBD 0,2 dan 0,3 mg/g OD pulp meningkatkan indeks tarik dari 30,5 $\mathrm{kNm} / \mathrm{g}$ menjadi $33,9 \mathrm{kNm} / \mathrm{g}$ dan $33,3 \mathrm{kNm} / \mathrm{g}$ atau sebesar $11 \%$ dan 9\% dibandingkan dengan blanko (Gambar 4). Karena CBD meningkatkan ikatan antar serat maka berpengaruh terhadap peningkatan indeks tarik lembaran kertas. Menurut Machado, dkk. (2009), aplikasi CBM3 dari Clostridium thermocellum scaffolding protein (CipA) pada pulp E. globulus meningkatkan indeks tarik dari $43 \mathrm{kNm} / \mathrm{g}$ menjadi $45 \mathrm{kNm} / \mathrm{g}$ atau meningkat sebesar $4,44 \%$. 


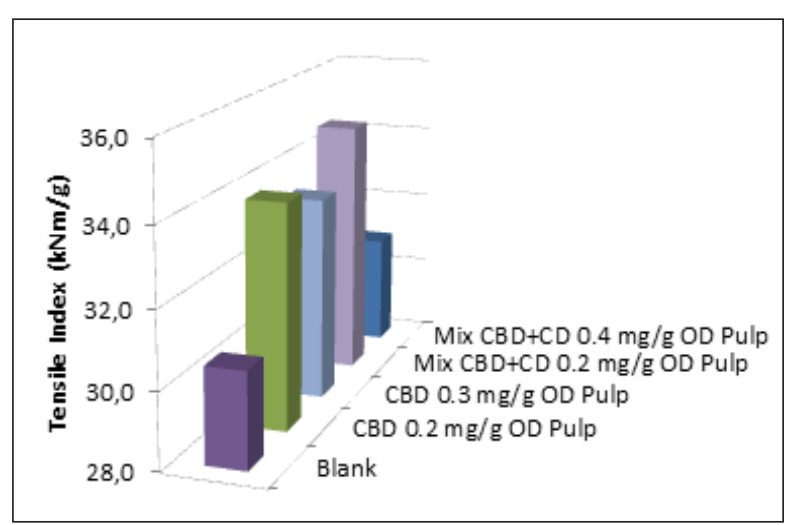

Gambar 4. Pengaruh Perlakuan CBD terhadap Tensile Index (Indeks Tarik)

Tujuan utama penggunaan CBD pada pembuatan kertas dari bahan kertas bekas adalah untuk meningkatkan freeness tanpa menurunkan kualitas kertas yang dihasilkan. Seperti telah dikemukaan sebelumnya, ternyata perlakuan dengan CBD selain dapat meningkatkan freeness juga dapat meningkatkan indeks tarik dan pada Gambar 5 juga dapat dilihat bahwa perlakuan dengan CBD 0,2 dan $0,3 \mathrm{mg} / \mathrm{g}$ OD pulp meningkatkan indeks retak dari $1,68 \mathrm{kPa} \cdot \mathrm{m}^{2} / \mathrm{g}$ menjadi $1,77 \mathrm{kPa} \cdot \mathrm{m}^{2} / \mathrm{g}$ dan $1,81 \mathrm{kPa} . \mathrm{m}^{2} / \mathrm{g}$ atau meningkat sebesar $5 \%$ dan $8 \%$ dibandingkan dengan blanko. Hal ini sesuai dengan penelitian yang telah dilakukan oleh Machado, dkk. (2009), aplikasi CBM3 dari Clostridium thermocellum scaffolding protein (CipA) pada pulp E. globulus meningkatkan indeks retak dari $2,7 \mathrm{kPa}$. $\mathrm{m}^{2} / \mathrm{g}$ menjadi $2,8 \mathrm{kPa} \cdot \mathrm{m}^{2} / \mathrm{g}$ atau meningkat sebesar $3,7 \%$.

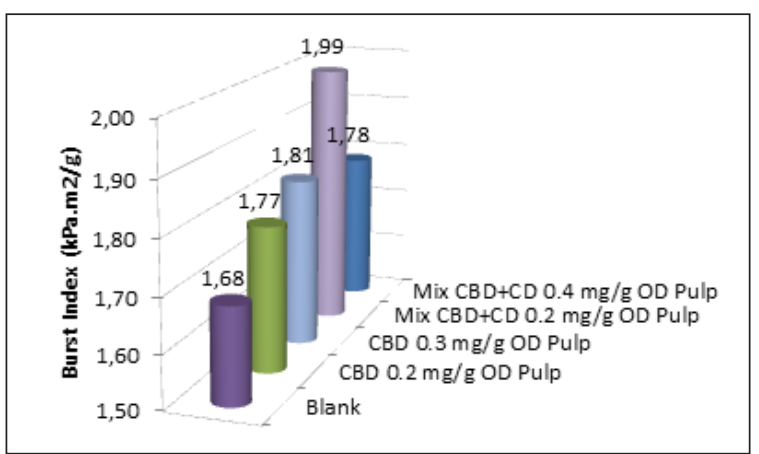

Gambar 5. Pengaruh Perlakuan CBD terhadap Burst Index (Indeks Retak).

Indeks sobek dipengaruhi oleh panjang serat. Perbaikan freeness dengan menggunakan campuran berbagai jenis selulase berdampak buruk berupa terjadinya degradasi serat (Pala, dkk., 2001; Dienes, 2006). Perlakuan dengan
CBD diharapkan tidak menyebabkan terjadinya degradasi serat atau turunnya indeks sobek. Pada Gambar 6 nampak bahwa perlakuan dengan CBD tidak mengubah indeks sobek, fakta ini didukung dengan tidak terdeteksinya selobiosa terlarut pada filtrat pulp kertas bekas (Tabel 2). Perlakuan dengan campuran CD-CBD-(Egl-II) $0,4 \mathrm{mg} / \mathrm{g}$ OD pulp menurunkan indeks sobek dari $6,2 \mathrm{mNm}^{2} / \mathrm{g}$ menjadi $5,6 \mathrm{mNm}^{2} / \mathrm{g}$ artinya telah terjadi degradasi serat sedangkan pada dosis lebih rendah $(0,2 \mathrm{mg} / \mathrm{g}$ OD pulp) hidrolisis serat kertas bekas masih terkendali.

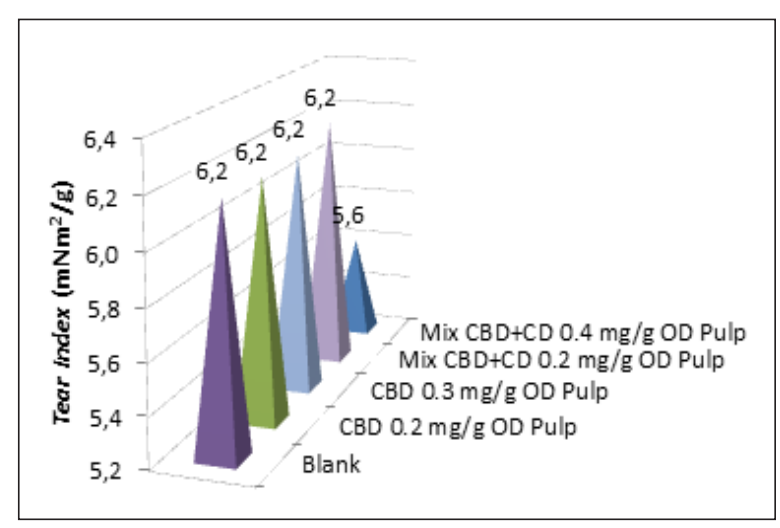

Gambar 6. Pengaruh Perlakuan CBD terhadap Tear Index (Indeks Sobek).

Perlakuan serat kertas bekas dengan CBD meningkatkan nilai ketahanan tekan lingkar dari $63,18 \mathrm{~N}$ menjadi $68,96 \mathrm{~N}$ dan $69,70 \mathrm{~N}$ karena CBD meningkatkan kekuatan kertas (Gambar 7). Nilai ketahanan tekan lingkar dapat digunakan untuk memprediksi ketahanan tekan kotak karton gelombang (Markstorm, 2006).

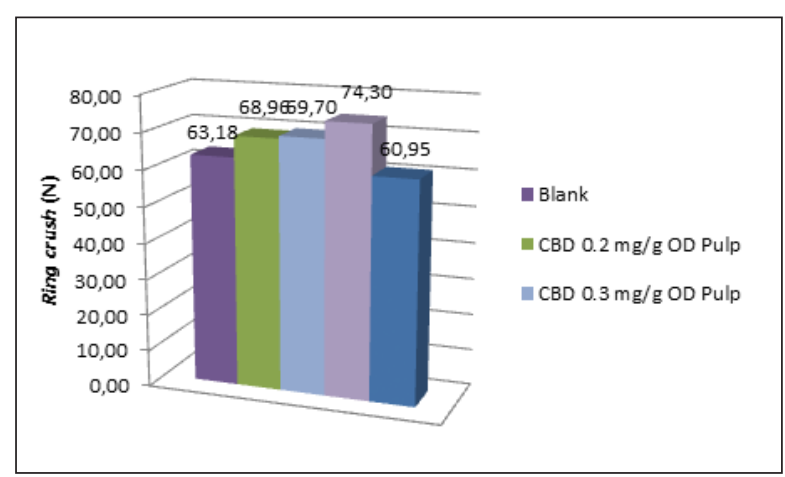

Gambar 7. Pengaruh Perlakuan CBD terhadap Ring Crush (Ketahanan Tekan Lingkar)

Sama halnya dengan ketahanan tekan lingkar, perlakuan serat kertas bekas dengan CBD meningkatkan nilai ketahanan tekan 
datar dari 85,28 $\mathrm{N}$ menjadi $86,76 \mathrm{~N}$ dan 92,54 N (Gambar 8). CMT adalah parameter mutu untuk menentukan kualitas kertas medium yang digunakan sebagai fluting medium pada kotak karton gelombang.

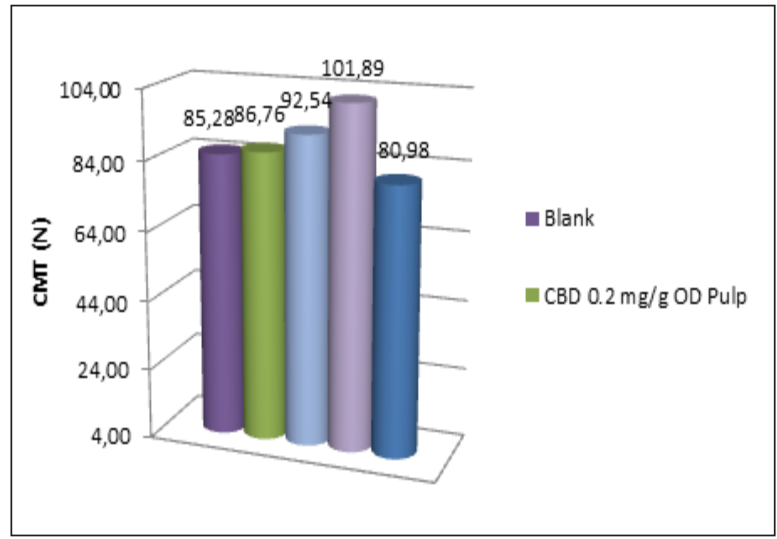

Gambar 8. Pengaruh Perlakuan CBD terhadap Concora Medium Test (CMT) atau Ketahanan Tekan Datar

\section{KESIMPULAN}

Dosis CBD yang digunakan untuk perlakuan terhadap serat kertas bekas adalah 0,2 dan $0,3 \mathrm{mg} \mathrm{CBD} / \mathrm{g}$ of oven dried pulp. Hasil penelitian menunjukkan perlakuan dengan CBD meningkatkan freeness bubur serat kertas bekas sebesar $140 \mathrm{~mL}$ CSF (70\%).CBD juga meningkatkan volume air yang dihilangkan dari serat kertas bekas dari $290 \mathrm{~mL}$ menjadi $390 \mathrm{~mL}$ dan $370 \mathrm{~mL}$ menggunakan pengukuran dynamic drainage jar (DDJ). \%FPR meningkat dari 98,80\% menjadi $99,77 \%$ Pengujian selobiosa terlarut pada filtrate serat kertas bekas yang telah mengalami perlakuan dengan CBD memperlihatkan tidak ada gula terlarut, artinya tidak ada degradasi selulosa menjadi gula terlarut. Indeks sobek dari kertas yang dihasilkan melalui perlakuan dengan CBD memperlihatkan tidak ada perubahan yang signifikan. Nilai Tensile index, burst index, ring crush dan CMT dari kertas yang dihasilkan melalui perlakuan dengan CBD meningkat.

\section{UCAPAN TERIMA KASIH}

Penelitian ini didanai melalui DIPA 2013 BBPK, Kementerian Perindustrian. Ucapan terima kasih disampaikan kepada Cucu, Enung F. M., Dadang S. A., Sonny K. W., Nena, dan seluruh karyawan BBPK yang telah mendukung penelitian ini. Ucapan terima kasih juga disampaikan ke Laboratorium Biokimia, Institut Teknologi Bandung yang telah menyediakan Bacillus megaterium yang membawa plasmid $\mathrm{PMM}_{1525 \text {-egII }}$

\section{DAFTAR PUSTAKA}

Bradford, M.M., 1976. A rapid and sensitive method for the quantitation of microgram quantities of protein utilizing the principle of protein-dye binding. Analytical Biochemistry, Vol. 72, 248-254

Carrard, G., Koivula, A., Soderlund, H., Beguin, P.. 2000. Cellulose-binding domains promote hydrolysis of different sites on crystalline cellulose. Proceedings of the National Academy of Sciences of the United States of America, Vol. 97 (19): 10342-10347

Dienes, D., 2006, "Effect of cellulase enzymes on secondary fiber properties". Ph. D. Thesis, Budapest University of Technology and Economics,Budapest, Hungaria

Direktorat Jenderal Industri Agro dan Kimia (Ditjen IAK), 2011. Roadmap Industri Kertas, Kementerian Perindustrian, Jakarta

Henrissat, B., Davies, G. J., 2000. Glycoside Hydrolases and Glycosyltransferases. Families, Modules, and Implications for Genomics. Plant Physiology, Vol. 124, 1515-1519.

Lemos, M. A., Teixeira, J. A., Mota, M., Gama, F. M., 2000. A simple methode to separate cellulose-binding domains of fungal cellulases after digestion by protease. Biotechnology Letters. Vol. 22: 703-707

Lestari, P., Richana, N., Murdiyatmo, U., 2000. Pemurnian $\alpha$-Amilase Bacillus stearothermophilus dengan Membran Ultrafiltrasi. Jurnal Mikrobiologi Indonesia. Vol. 5(1) : 10-14.

Levy, I. dan Shoseyov, O.. 2002. Cellulose-binding domains Biotechnological applications. Biotechnology Advances. Vol. 20 : 191-213

Machado, J., Arau'jo, A., Pinto, R., Gama, F. M., 2009. Studies on the interaction of the carbohydrate binding module 3 from the Clostridium thermocellum CipA scaffolding protein with cellulose and paper fibres. Cellulose. Vol. 16, 817-824

Markstrom, H. 2005. Testing Methods and Instruments for Corrugated Board. AB Lorentzen \& Wettre, Swedia

Masriani, R., 2011, "Aplikasi Rekombinan Endoglukanase EglII untuk Modifikasi Serat Kertas Bekas", Tesis, Institut Teknologi Bandung, Bandung 
Masriani, R. dan Nurachman, Z., 2012. Modifikasi serat kertas bekas menggunakan endoglukanase Egl-II. Jurnal Selulosa. Vol. 2, No. 2, 53-60

Masriani, R., Hidayat, T., Trisulo, D. C., 2013. Pemisahan Cellulose-Binding Domain dari Endoglukanse Egl-II dengan Metode Proteolisis. Jurnal Selulosa. Vol. 3, No. 1, $35-42$

Miller, G. L., 1959. Use of dinitrosalicylic acid reagent for determination of reducing sugar. Analytical Chemistry, $31: 426-428$

MoBiTec, 2008. Bacillus megaterium Protein Expression System, Molecular Biologische Technologie. Jerman.

Nurachman,Z., Kurniasih, S.D., Puspitawati, F., Hadi, S., Radjasa, O. K., Natalia, D., 2010. Cloning of the Endoglucanase Gene from a Bacillus amyloliquefaciens PSM 3.1 in Escherichia coli Revealed Catalytic Triad Residues Thr-HisGlu. American Journal of Biochemistry and Biotechnology, 6 (4): 268-274.
Pala, H., Lemos, M. A., Mota, M., Gama, F. M.. 2001. Enzymatic upgrade of old paperboard containers. Enzyme and Microbial Technology. $29: 274-279$.

Wittchen, K.D. dan Meinhardt, F. 1995. Inactivation of the major extracellular protease from Bacillus megaterium DSM319 by gene replacement. Applied Microbiology and Biotechnology 42: 871-877.

Yokota, S., K. Matsuo, T. Kitaoka, H. Wariishi, 2008. Specific interaction acting at a cellulose-binding domain/cellulose interface for papermaking application. BioResources 3(4): 1030-1041.

Yokota, S., K. Matsuo, T. Kitaoka, H. Wariishi, 2009. Retention and Paper-Strength Characteristics of Anionic Polyacrylamides Conjugated with Carbohydrate-Binding Modules. BioResources, Vol.4 (1), 234244. 